\section{Klinische opleiding in de academie en de periferie}

Parry J, Mathers J, Al-Fares A, Mohammad M., Nandakumar M., Tsivos D. Hostile teaching hospitals and friendly district general hospitals: final year students' views on clinical attachment locations. Med Educ 2002;36(12): 1131-41.

Net als in Nederland zullen er in Groot-Brittannië de komende jaren meer artsen moeten worden opgeleid: rond 2005 57\% meer dan in 1997. Hierdoor ontstaat er grote nood aan goede, klinische opleidingsplaatsen. Het betrekken van de perifere ziekenhuizen bij de opleiding wordt in de toekomst derhalve steeds belangrijker.

Het artikel van Parry et al. gaat in op de verschillen met betrekking tot de klinische opleiding tussen een academisch ziekenhuis, een geaffilieerd ziekenhuis dat afhankelijk is van de medische faculteit waar de input van de universitaire staf groot is en waar veel onderzoek gedaan wordt, en een perifeer ziekenhuis gelegen in de regio en zonder binding met de medische faculteit zoals hoger beschreven.

Alle laatstejaars studenten geneeskunde van het cohort 2000-2001 aan de universiteit van Birmingham kregen een vragenlijst met in totaal 19 vragen waarin respectievelijk de kwaliteit van de training ( 9 vragen), de klinische en praktische ervaringen (7 vragen) en de algemene indrukken van de opleidingsplaatsen (3 vragen) bevraagd werden. De respons bedroeg $80 \%$.

Uit de enquête kwam naar voren dat er in het algemeen weinig onderscheid bestaat tussen een universitair ziekenhuis en een perifeer ziekenhuis voor wat betreft het werken met leer- doelen en het ervoor zorg dragen dat die leerdoelen ook kunnen gehaald worden in de klinische setting. Desalniettemin zijn er duidelijke en consistente verschillen waar te nemen tussen deze twee settingen. In de perifere ziekenhuizen is de leersituatie vriendelijker en meer ondersteunend, maar de leerfaciliteiten zijn slechter. De opleiders in de periferie zijn toegankelijker en beter beschikbaar voor vragen dan hun collega's in het academische ziekenhuis. Ze lassen opleidingssessies minder snel af en zijn meer aanwezig. In de universitaire ziekenhuizen leren studenten minder van de bedside teaching, omdat ze met teveel zijn en niet de kans krijgen om zelf te onderzoeken en te oefenen. In de periferie krijgen de studenten meer kans om gewone praktische procedures te oefenen. Ze krijgen een breder gamma te zien van klinische condities. Er is meer kans om patiënten te onderzoeken en zelf de opname van patiënten te doen. Uiteraard zijn er meer transportproblemen en verblijfsproblemen voor de studenten en daardoor ook grotere kosten in een perifeer ziekenhuis.

Het wordt een grote uitdaging om de grotere aantallen studenten in de komende jaren goed klinisch onderwijs te kunnen geven. In ieder geval moeten we ervoor waken dat de voordelen van de perifere ziekenhuizen met de schaalvergroting niet verloren gaan.

Kwaliteit van opleiden vergt professionalisering van de opleiders en tijd. Tijd die toch al schaars is door de grote werkdruk en het tekort aan artsen. Nieuwe strategieën en trainingsmodellen zijn noodzakelijk om dit politiek gecreëerd probleem op te lossen.

Joke Denekens

Antwerpen 